\title{
SDHB Gene Mutation
}

National Cancer Institute

\section{Source}

National Cancer Institute. SDHB Gene Mutation. NCI Thesaurus. Code C48302.

A change in the nucleotide sequence of the SDHB gene. 